that Bolton's testimony would supply the firsthand evidence against Trump that Republicans claimed was lacking. ${ }^{64}$ On January 31, the Senate voted 51-49 not to hear from additional witnesses, with two Republican Senators joining the forty-seven Democrats who favored hearing from these witnesses. ${ }^{65}$

On February 5, the Senate voted to acquit Trump on both charges. ${ }^{66}$ Fifty-two Republicans voted "not guilty" on the abuse of power charge, while Republican Senator Mitt Romney and all forty-seven Democrats voted "guilty." 67 All fifty-three Republicans voted "not guilty" on the obstruction of justice charge, while all forty-seven Democrats voted "guilty." 68 Trump thus became the third president in U.S. history to be impeached but not convicted. ${ }^{69}$

\title{
Trump Administration Further Restricts Asylum Seekers at the Southern Border Through the Migrant Protection Protocols, Asylum Cooperative Agreements, and COVID-19 Procedures doi:10.1017/ajil.2020.41
}

During the spring of 2020, the Trump administration continued efforts to reduce the ability of individuals to seek asylum in the United States, particularly at its southern border. The administration received temporary authorization from the U.S. Supreme Court to put into effect the Migrant Protection Protocols (MPP)—an arrangement that requires non-Mexican asylum seekers to wait in Mexico for the duration of their immigration proceedings-while the administration petitions the Court to reverse a lower court decision enjoining the MPP's implementation. The administration has also sought to implement its asylum cooperative agreement with Guatemala, whereby the United States sends certain non-Guatemalan migrants to Guatemala to apply for asylum there. The legality of this agreement is presently being challenged, and, in March of 2020, the COVID-19 pandemic caused Guatemala to stop

\footnotetext{
${ }^{64}$ John Wagner, Democrats Make Final Case for Why Senate Needs to Hear from Bolton, Mulvaney, WASH. POST (Jan. 31, 2020), at https://www.washingtonpost.com/politics/impeachment-trial-live-updates/2020/01/31/ 9a853bbe-4415-11ea-b5fc-eefa848cde99_story.html.

${ }^{65}$ Michael Brice-Saddler, Senate Votes to Formally Reject Additional Witnesses, Evidence, WaSH. POST (Jan. 31, 2020), at https:/www.washingtonpost.com/politics/impeachment-trial-live-updates/2020/01/31/9a853bbe4415-11ea-b5fc-eefa848cde99_story.html.

66 All Actions H.Res.755 - 116th Congress (2019-2020), Congress.Gov, at https://www.congress.gov/bill/ 116th-congress/house-resolution/755/all-actions?overview $=$ closed $\&$ KWICView $=$ false.

${ }^{67}$ Roll Call Vote 116th Congress - 2d Session (Vote 33), at https://www.senate.gov/legislative/LIS/roll_call_lists/roll_call_vote_cfm.cfm?congress $=1168$ session $=2 \&$ vote $=00033$.

${ }^{68}$ Roll Call Vote 116th Congress - 2d Session (Vote 34), at https://www.senate.gov/legislative/LIS/roll_call_lists/roll_call_vote_cfm.cfm?congress $=116 \&$ session $=2 \&$ vote $=00034$.

${ }^{69}$ Two days after the conclusion of the trial, Trump took action against some of the witnesses who participated in the congressional inquiry, removing one from the National Security Council staff and recalling Sondland from his position as Ambassador to the European Union. See Scott R. Anderson, The Legal Limits on Trump's Reprisals Against Impeachment Witnesses, LAWFARE (Feb. 11, 2020), at https://www.lawfareblog.com/legal-limits-trumpsreprisals-against-impeachment-witnesses (noting that "[b]y the end of the day, no one who participated in the House's impeachment proceedings still held a White House position or ambassadorship").
} 
accepting flights of migrants sent by the U.S. government. Citing COVID-19, the Trump administration itself issued various suspensions of entry into the United States of noncitizens during the spring of 2020 , including with respect to asylum seekers at the U.S.-Mexico border.

The MPP requires most foreign nationals from countries other than Mexico "arriving in or entering the United States from Mexico-illegally or without proper documentation-[to return] to Mexico for the duration of their immigration proceedings." 1 Announcing the MPP in December of 2018, the secretary of Homeland Security stated that:

officials should act consistent with the non-refoulement principles contained in Article 33 of the 1951 Convention Relating to the Status of Refugees (1951 [Refugee] Convention) and Article 3 of the Convention Against Torture and Other Cruel, Inhuman or Degrading Treatment or Punishment (CAT). Specifically, a third-country national should not be involuntarily returned to Mexico . . . if the alien would more likely than not be persecuted on account of race, religion, nationality, membership in a particular social group, or political opinion (unless such alien has engaged in criminal, persecutory, or terrorist activity ...), or would more likely than not be tortured, if so returned pending removal proceedings. ${ }^{2}$

In February of 2019, individual migrants and advocacy groups filed a lawsuit in the Northern District of California seeking an order to vacate the MPP and enjoin government officials "from continuing to apply [the MPP] to third-party nationals seeking humanitarian protection." 3 As part of their arguments for relief, the plaintiffs noted that the MPP lacked the required "safeguards to ensure the critical protection against nonrefoulement" as found in Article 33 of the 1951 Refugee Convention and as required through the "specific, universal, and obligatory norm of customary international law." 4 On April 8, 2019, the federal district

${ }^{1}$ U.S. Dep't of Homeland Sec. Press Release, Secretary Kirstjen M. Nielsen Announces Historic Action to Confront Illegal Immigration (Dec. 20, 2018), at https://www.dhs.gov/news/2018/12/20/secretary-nielsenannounces-historic-action-confront-illegal-immigration [https://perma.cc/MT4X-XCME]; see also Jean Galbraith, Contemporary Practice of the United States, 113 AJIL 377, 384-85 (2019) (discussing the issuance of the MPP and describing Mexico's response).

${ }^{2}$ Memorandum from Kirstjen M. Nielsen, Sec'y of Homeland Sec., on Policy Guidance for Implementation of the Migrant Prot. Protocols to L. Francis Cissna, Director of U.S. Citizenship \& Immigration Servs. et al., at 3-4 (Jan. 25, 2019) (footnotes omitted), available at https://www.dhs.gov/sites/default/files/publications/ 19_0129_OPA_migrant-protection-protocols-policy-guidance.pdf [https://perma.cc/6RK3-KQLT]. The United States is a party to the 1967 Protocol Relating to the Status of Refugees, which incorporates the relevant articles of the Refugee Convention. Depositary Status for the Protocol Relating to the Status of Refugees, UNITED Nations Treaty Collection, https://treaties.un.org/pages/ViewDetails.aspx?src=TREATY\&mtdsg_no=V$5 \&$ chapter $=5$.

${ }^{3}$ Complaint for Declaratory and Injunctive Relief at 36, Innovation Law Lab v. Nielsen, No. 3:19-cv-00807 (N.D. Cal. Feb. 14, 2019), ECF No. 1. Among the individual plaintiffs were Plaintiff Bianca Doe, "a lesbian woman from Honduras" who "became pregnant by a man who raped her because of her sexual orientation"; Plaintiff John Doe, "an indigenous man from Guatemala who suffered brutal beatings and death threats" and was "targeted for his indigenous identity"; Plaintiff Ian Doe, "a former police officer from Honduras" who was targeted by drug traffickers for working in undercover drug interdiction activity; and Plaintiff Alex Doe, "a youth pastor and organizer from Honduras" who was "at risk of being forcibly recruited by gangs[, a]fter he helped organize a strike to protest the killing a young member of his church." Id. at 9-10.

${ }^{4} I d$. at $34-35$. 
court granted the plaintiffs' motion for preliminary injunction, ${ }^{5}$ although this injunction was stayed by the Ninth Circuit pending its consideration of the executive branch's appeal. ${ }^{6}$

On February 28, 2020, by a two-to-one vote, the Ninth Circuit affirmed the lower court's grant of a preliminary injunction setting aside the MPP. ${ }^{7}$ The court found that the plaintiffs were likely to succeed on the merits of their claim for two alternative reasons. One was that the provision of the Immigration and Nationality Act (INA) invoked by the executive branch as authorizing the MPP was not actually applicable. ${ }^{8}$ The second was that the "plaintiffs have shown a likelihood of success on their claim that the MPP does not comply with our treatybased nonrefoulement obligations codified" in the INA.?

In holding that the MPP does not comply with the statutorily mandated obligation of nonrefoulement, the Ninth Circuit determined that the MPP did not adequately protect asylumseekers from the risk of persecution in Mexico. The court noted the plaintiffs' argument that the Department of Homeland Security required too much of asylum seekers in insisting that they demonstrate it was "more likely than not" that they would face persecution in Mexico, as distinct from the lower "credible fear" threshold that had historically been applicable. ${ }^{10}$ The court also noted various arguments raised by plaintiffs for why the screening procedures set forth in the MPP were inadequate to ensure nonrefoulement. ${ }^{11}$ The court rejected the executive branch's argument that it would be a "rare case where an MPP-eligible alien does have a substantial and well-grounded basis for claiming that he is likely to be persecuted in Mexico." 12 The court observed:

The Government points to no evidence supporting its speculations either that aliens, unprompted and untutored in the law of refoulement, will volunteer that they fear returning to Mexico, or that there is little danger to non-Mexican aliens in Mexico ....

Several [plaintiffs] described violence and threats of violence in Mexico. Much of the violence was directed at [these plaintiffs] because they were non-Mexican-that is, because of their nationality, a protected ground under asylum law. ${ }^{13}$

\footnotetext{
${ }^{5}$ Innovation Law Lab v. Nielsen, 366 F. Supp. 3d 1110, 1114 (N.D. Cal. 2019).

${ }^{6}$ Innovation Law Lab v. McAleenan, 924 F.3d 503 (9th Cir. 2019).

${ }^{7}$ Innovation Law Lab v. Wolf, 951 F.3d 1073, 1080, 1093, 1095 (9th Cir. 2020).
}

${ }^{8}$ The provision at issue states that "the Attorney General may return the alien . . who is arriving on land (whether or not at a designated port of arrival) from a foreign territory contiguous to the United States . . to that territory pending" removal proceedings. 8 U.S.C. $\$ 1225(\mathrm{~b})(2)(\mathrm{C})$. The executive branch interpreted this provision to apply to asylum seekers who lacked proper documentation, but the Ninth Circuit held that this provision applied only to persons inadmissible for other, specific reasons, such as having previously committed a crime of moral turpitude. See Innovation Law Lab, 951 F.3d at 1082-87 (concluding that this provision applied to persons described in 8 U.S.C. $\$ 1225$ (b)(2) and not to persons described in 8 U.S.C. $\$ 1225(\mathrm{~b})(1)$ ).

${ }^{9}$ Innovation Law Lab, 951 F.3d at 1081. The nonrefoulement obligations codified at 8 U.S.C. $\$ 1231(\mathrm{~b})$ are as follows: "[T]he Attorney General may not remove an alien to a country if the Attorney General decides that the alien's life or freedom would be threatened in that country because of the alien's race, religion, nationality, membership in a particular social group, or political opinion." 8 U.S.C. $\$ 1231(\mathrm{~b})(3)(\mathrm{A})(2018)$.

${ }^{10}$ Innovation Law Lab, 951 F.3d at 1088-89; $c$. id. at 1090 (rejecting the executive branch's argument that the statutory protection against nonrefoulement invoked by the plaintiffs was inapplicable for purposes of the MPP).

${ }^{11} \mathrm{Id}$. at 1089.

${ }^{12} I d$. at 1090 .

${ }^{13} I d$. 
On March 6, 2020, the executive branch asked the Supreme Court to block the preliminary injunction against the MPP from taking effect while the executive branch sought full Supreme Court review of the Ninth Circuit's decision. ${ }^{14}$ On March 11, 2020, the Supreme Court stayed the preliminary injunction, thus leaving the MPP in effect "pending the filing and disposition of a petition for a writ of certiorari." 15 The Supreme Court order stated that "Justice Sotomayor would deny" the executive branch's request for a stay. ${ }^{16}$

The Trump administration's efforts to restrict the ability of individuals to seek asylum in the United States have been pursued through other methods besides the MPP. One such method is the negotiation of asylum cooperative agreements, sometimes referred to as safe third-country agreements-agreements by which the United States sends asylum seekers to pursue their asylum claims in countries other than the one from which they are fleeing. In 2019, the Trump administration negotiated such agreements with Guatemala, Honduras, and El Salvador; previously, the only such agreement had been a longstanding, two-way agreement with Canada. ${ }^{17}$ The Trump administration reportedly also attempted to negotiate

\footnotetext{
${ }^{14}$ See Application for a Stay of the Injunction Issued by the United States District Court for the Northern District of California and for an Administrative Stay, Wolf v. Innovation Law Lab, No. 19A960 (U.S. Mar. 6, 2020). Following its decision of February 28, the Ninth Circuit briefly stayed the implementation of the district court's injunction, but on March 4, by a two-to-one vote, it lifted this stay with respect to asylum-seekers crossing into California or Arizona-states within the direct purview of the Ninth Circuit. Innovation Law Lab v. Wolf, 951 F.3d 986, 987 (9th Cir. 2020). In this decision of March 4, the Ninth Circuit noted but declined to assess dueling statements submitted by the parties with respect to the implications of the MPP's suspension for relations
} between the United States and Mexico. Id. at 990-91.

15 Wolf v. Innovation Law Lab, No. 19A960, 2020 WL 1161432, at*1 (U.S. Mar. 11, 2020).

${ }^{16}$ Id. On April 10, 2020, the Department of Justice filed a petition for writ of certiorari, and it is currently pending before the Supreme Court. Petition for a Writ of Certiorari, Wolf v. Innovation Law Lab, No. 191212 (U.S. Apr. 10, 2020). This stay was not the only one issued recently by the Supreme Court with respect to immigration law. In September of 2019, over two dissenting votes, the Supreme Court stayed a preliminary injunction with respect to a different asylum-related rule issued by the Trump administration. See Jean Galbraith, Contemporary Practice of the United States, 113 AJIL 833, 834-37 (2019) (describing these proceedings and this rule, which bars individuals crossing the southern U.S. border from applying for asylum in the United States if they have not applied for asylum in third countries through which they have transited). On January 27, 2020, by a fiveto-four vote, the Supreme Court stayed a preliminary injunction barring the implementation of a rule, issued by the Trump administration, that makes it significantly more difficult for certain noncitizens present in the United States to extend their stays or adjust their statuses if they have received various public benefits in the past. Dep't of Homeland Sec. v. New York, 140 S. Ct. 599, 599 (2020); see also Wolf v. Cook County, 140 S. Ct. 681 (2020) (issuing a further, related stay over four dissenting votes on Feb. 21, 2020); cf. Inadmissibility on Public Charge Grounds, 84 Fed. Reg. 41292, 41486 (Aug. 14, 2019). The Supreme Court is also presently considering Department of Homeland Security $v$. Regents of the University of California, a challenge to the Trump administration's rescission of the Deferred Action for Childhood Arrivals (DACA) program instituted by the Obama administration to give work eligibility to certain migrants who entered the United States as children without proper documentation. The Supreme Court heard oral argument in this case on November 12, 2019 and, as of late May 2020, the case is still pending. See Docket, DHS v. Regents of Univ. of Cal., Nos. 18-587, 18-588, 18-589 (U.S. Nov. 12, 2019). Mexico filed an amicus brief in this case arguing that "[a]llowing DACA to continue will serve [the] mutual national interests" of Mexico and the United States. Brief of Amicus Curiae Gov. of the United Mexican States in Support of Respondents 3, DHS v. Regents of Univ. of Cal., Nos. 18-587, 18-588, 18-589 (U.S. Oct. 3, 2019); see also id. at 28 (arguing that DACA facilitates the U.S. obligation under the International Covenant on Civil and Political Rights to protect the family unit). Other challenges to immigration-related rules are ongoing in the lower courts. E.g., Doe \#1 v. Trump, 957 F.3d 1050, 1056 (9th Cir. 2020) (denying the executive branch's motion "to stay the district court's preliminary injunction enjoining a Presidential Proclamation restricting family-sponsored immigrants from entering the United States without acquiring specified health insurance”).

${ }^{17}$ Implementing Bilateral and Multilateral Asylum Cooperative Agreements Under the Immigration and Nationality Act, 84 Fed. Reg. 63,994, 63,994 (Nov. 19, 2019) [hereinafter Regulation on the Implementation of Asylum Cooperative Agreements] (setting out general procedures for the implementation of such agreements 
a similar agreement with Panama, but its efforts to do so in 2019 were unsuccessful. ${ }^{18}$ The Department of Homeland Security has generally described these agreements as:

[B] etween the United States and foreign countries where aliens removed to those countries would have access to a full and fair procedure for determining a claim to asylum or equivalent temporary protection. In certain circumstances, an [asylum cooperative agreement] . . bars an alien subject to the agreement from applying for asylum in the United States and provides for the removal of the alien, pursuant to the agreement, to a country that will provide access to a full and fair procedure for determining the alien's protection claim. ${ }^{19}$

On January 15, 2020, individual plaintiffs and legal organizations filed a lawsuit in the District of Columbia challenging these agreements. They stated that "Guatemala, Honduras, and El Salvador [are] extremely dangerous, refugee-producing countries with asylum systems that are skeletal at best." ${ }^{20}$ Among other claims, they argued that the implementation of these agreements contradicts statutory requirements and is arbitrary and capricious. More generally, it

cast $[s]$ aside our asylum laws, which reflect Congress's carefully considered balance between effectuating our broad historical commitment to protecting refugees fleeing persecution and torture-a commitment with origins in the 1951 United Nations Convention Relating to the Status of Refugees - and ensuring fairness and efficiency in the asylum process. ${ }^{21}$

As of late May of 2020, the plaintiffs' motion for summary judgment remained pending in the federal district court. ${ }^{22}$ By March of 2020, the United States had sent hundreds of

but excepting the preexisting agreement with Canada). For a longer discussion of these agreements, see Galbraith, supra note 16, at 834, 837-39 (observing that the United States threatened economic sanctions unless these agreements were negotiated, describing challenges in Guatemala to the legality of its agreement with the United States, and noting that grave concerns had been raised about whether these countries could adequately protect asylumseekers from human rights violations).

${ }^{18}$ Nick Miroff, U.S. Seeks Deal to Send Asylum Seekers from Africa and Asia to Panama, WASH. Post (Aug. 21, 2019), at https://www.washingtonpost.com/immigration/us-seeks-deal-to-send-asylum-seekers-from-africa-andasia-to-panama/2019/08/20/30bbde66-c37f-11e9-9986-1fb3e4397be4_story.html (noting DHS Secretary Kevin McAleenan's plans to travel to Panama to "discuss regional cooperation to confront irregular migration," as part of the Trump administration's efforts to secure asylum cooperative agreements); Panama to US: We Won't Be Your "Safe Third Country," TELESUR (Aug. 22, 2019), at https://www.telesurenglish.net/news/Panama-to-USWe-Wont-be-Your-Safe-Third-Country-20190822-0014.html (noting the negative response of Panama's president to the prospect of an asylum cooperative agreement).

${ }^{19}$ Regulation on the Implementation of Asylum Cooperative Agreements, supra note 17, at 63,994; see also id. at 64,001 (providing that the asylum cooperative agreements do not require that a migrant "have transited through the relevant third country ... or arrive[d] at ports of entry" and further providing that a migrant will not be transmitted to a third country if, during a screening, it is deemed "more likely than not" that the person's "life or freedom would be threatened in the third country on account of a protected ground or that the [person] would be tortured in the third country").

${ }^{20}$ Complaint for Declaratory and Injunctive Relief at 1, U.T. v. Barr, No. 1:20-cv-00116 (D.D.C. Jan. 15, 2020), ECF No. 3; see also id. at 2 (noting that these countries "have extremely high murder rates, rampant genderbased violence, and virtually no ability to receive asylum seekers").

${ }^{21} I d$. at 4 .

${ }^{22}$ See generally Docket, U.T. v. Barr, No. 1:20-cv-00116 (D.D.C. 2020). 
Honduran and El Salvadorian migrants to Guatemala. ${ }^{23}$ That month, however, concerns about the COVID-19 pandemic caused the Guatemala government to suspend U.S. flights of migrants. ${ }^{24}$

In the early months of 2020, the Trump administration took further steps to restrict the entry of noncitizens into the United States across the southern border and more generally. On January 31, 2020, President Trump suspended the entry of certain categories of immigrants from Myanmar, Eritrea, Kyrgyzstan, Nigeria, Sudan, and Tanzania, relying on the same authority that he had invoked several years earlier in banning the entry of foreign nationals from a handful of other, mostly Muslim-majority countries. ${ }^{25}$ That same day, Trump issued his first travel restriction related to the COVID-19 pandemic, prohibiting the entry of certain categories of noncitizens "who were physically present within the People's Republic of China, excluding the Special Administrative Regions of Hong Kong and Macau, during the 14-day period preceding their entry or attempted entry into the United States." 26 On February 29, stating that "Iran is not a trustworthy state actor" and that the "United States Government is therefore unable to rely on official information disseminated by Iran," Trump prohibited the entry into the United States of certain categories of noncitizens "who were physically present within Iran during the 14-day period preceding their entry or attempted entry." 27

In March, as the COVID-19 pandemic was sweeping through the United States, the Trump administration initiated further restrictions on entry. On March 11, 2020, Trump barred the entry of certain categories of noncitizens "who were physically present within the Schengen Area during the 14-day period preceding their entry or attempted entry into the United States." 28 On March 14, Trump similarly barred entry of certain categories of noncitizens from the United Kingdom and Ireland. ${ }^{29}$ These restrictions, like the earlier ones regarding China and Iran, are "in effect until terminated by the President."30

\footnotetext{
${ }^{23}$ Reynaldo Leaños Jr., Asylum-Seekers Reaching U.S. Border Are Being Flown to Guatemala, NPR (Mar. 11, 2020), at https://www.npr.org/2020/03/11/814602596/asylum-seekers-reaching-u-s-border-are-being-flownto-guatemala (noting that only about sixteen of these migrants, according to Guatemalan officials, have applied for asylum there).

${ }^{24}$ Zolan Kanno-Youngs, Michael D. Shear \& Maggie Haberman, Citing Coronavirus, Trump Will Announce Strict New Border Controls, N.Y. Times (Mar. 17, 2020), at https://www.nytimes.com/2020/03/17/us/politics/ trump-coronavirus-mexican-border.html ("The coronavirus outbreak has also halted a Trump administration program that had diverted to Guatemala more than 900 asylum seekers trying to enter the United States. The government there suspended the flights as a way to prevent the domestic spread of the virus."); Sofia Menchu, Guatemala Suspends Deportation, Asylum Flights From U.S., ReuTERS (Mar. 17, 2020), at https:// www.reuters.com/article/us-usa-immigration-guatemala/guatemala-suspends-deportation-asylum-flights-fromu-s-idUSKBN2143C2 ("In a statement, Guatemala's Foreign Ministry said it had suspended the flights until proper sanitary protocols could be established in the country to permit the safe return of the people to their places of origin").

25 Proclamation No. 9983, 85 Fed. Reg. 6699, 6702 (Jan. 31, 2020) (stating that these countries had "deficiencies in sharing terrorist, criminal, or identity information"). For a description of the prior travel bans and the resulting litigation, see Jean Galbraith, Contemporary Practice of the United States, 112 AJIL 741 (2018). Also in January of 2020, the Department of State released a rule restricting visas that might lead to what it termed "birth tourism." Visas: Temporary Visitors for Business or Pleasure, 85 Fed. Reg. 4219, 422122 (Jan. 24, 2020).

26 Proclamation No. 9984, 85 Fed. Reg. 6709, 6710 (Jan. 31, 2020).

27 Proclamation No. 9992, 85 Fed. Reg. 12,855, 12,855 (Feb. 29, 2020).

${ }^{28}$ Proclamation No. 9993, 85 Fed. Reg. 15,045, 15,046 (Mar. 11, 2020).

${ }^{29}$ Proclamation No. 9996, 85 Fed. Reg. 15,341 (Mar. 14, 2020).

30 See, e.g., id. at $15,343$.
} 
On March 20, the Trump administration announced the temporary suspension of the entry of all undocumented individuals who cross the southern border with Mexico and the northern border with Canada at ports of entry or at places where they would be taken to border patrol stations. ${ }^{31}$ In this order, the Centers for Disease Control and Prevention (CDC) stated that "inadmissible aliens" involve longer screening processes, congregate hours or days in areas while undergoing processing, and are in close proximity to U.S. border personnel and other travelers. ${ }^{32}$ The order had no categorical exceptions for asylum-seekers, persons fleeing torture, or unaccompanied minors. ${ }^{33}$ As authority for this broad order, the administration cited the 1944 Public Health Service Act, which authorizes the surgeon general to suspend "in whole or in part, the introduction of persons and property" when there is "serious danger of the introduction of [a communicable] disease into the United States" and a "suspension ... is required in the interest of public health." 34 Critics have argued that this order violates federal statutory protections for asylum-seekers and torture victims and more generally that, as one critic stated, it "deploys a medical quarantine authorization to override the protections of the immigration and refugee laws through the use of an unreviewable Border Patrol health 'expulsion' mechanism unrelated to any finding of disease or contagion." 35

On April 22, 2020, Trump cited COVID-19 in proclaiming yet another travel restrictionthis one temporarily suspending, subject to certain exceptions, the entry into the United States of all persons traveling on immigrant visas whose visas or other travel documents were not yet operational as of the date of the proclamation. ${ }^{36}$ Unlike the other COVID-19 travel restrictions, the justification identified for this one related to economic stability rather than health. The proclamation pointed to "the impact of foreign workers on the United States labor market, particularly in an environment of high domestic unemployment and depressed demand for labor," as well as noting the need to "conserve critical State Department resources so that consular officials may continue to provide services to United States citizens

\footnotetext{
${ }^{31}$ Notice of Order Under Sections 362 and 365 of the Public Health Service Act Suspending Introduction of Certain Persons From Countries Where a Communicable Disease Exists, 85 Fed. Reg. 17,060, 17,060-61 (Mar. 26, 2020) [hereinafter Border Suspension Notice]. These travel restrictions were set to expire within thirty days from March 20, 2020. Id. Both restrictions were extended on April 21, 2020 until May 20, 2020. Notification of Temporary Travel Restrictions Applicable to Land Ports of Entry and Ferries Service Between the United States and Canada, 85 Fed. Reg. 22,352 (Apr. 21, 2020); Notification of Temporary Travel Restrictions Applicable to Land Ports of Entry and Ferries Service Between the United States and Mexico, 85 Fed. Reg. 22,353 (Apr. 21, 2020). These restrictions were again extended on May 21, 2020 until June 22, 2020. Notification of Temporary Travel Restrictions Applicable to Land Ports of Entry and Ferries Service Between the United States and Canada, 85 Fed. Reg. 31,059 (May 21, 2020); Notification of Temporary Travel Restrictions Applicable to Land Ports of Entry and Ferries Service Between the United States and Mexico, 85 Fed. Reg. 31,057 (May 21, 2020). As of late May of 2020, it is unclear whether there will be further extensions of these restrictions.

32 Border Suspension Notice, supra note 31, at 17,065.

33 See generally id. (allowing for case-by-case exceptions to the overall order "based on the totality of the circumstances, including consideration of significant law enforcement, officer and public safety, humanitarian, and public health concerns").

${ }^{34} I d$. at 17,088; 42 U.S.C. $\$ 265$ (2018).

${ }^{35}$ Lucas Guttentag, Coronavirus Border Expulsions: CDC's Assault on Asylum Seekers and Unaccompanied Minors, JUST SECURITY (Apr. 13, 2020), at https://www.justsecurity.org/69640/coronavirus-border-expulsions-cdcsassault-on-asylum-seekers-and-unaccompanied-minors (discussing the tensions between this order and the rights of undocumented migrants secured by the 1980 Refugee Act, the prohibitions on refoulement under the 1951 Refugee Convention, and the mandatory protection from torture under CAT and its implementing legislation).

${ }^{36}$ Proclamation No. 10014, 85 Fed. Reg. 23,441 (Apr. 22, 2020). This restriction has an initial sixty-day limit; as of late May of 2020, it remains to be seen whether it will be extended. See id. at 23,443.
} 
abroad." ${ }^{37}$ After a surge of COVID-19 cases in Brazil, on May 24, 2020, Trump imposed travel restrictions on certain categories of noncitizens "physically present within the Federative Republic of Brazil during the 14-day period preceding their entry or attempted entry into the United States." 38

\section{STATE JURISDiCTION AND IMMUNITY}

\section{U.S. Department of Justice Indicts Venezuelan Leader Nicolás Maduro on Narcotrafficking Charges}

doi:10.1017/ajil.2020.42

On March 26, 2020, the U.S. Department of Justice (DOJ) announced the indictment of Venezuelan leader Nicolás Maduro, along with fourteen current and former regime officials, on charges mostly related to drug trafficking. Specifically, an indictment unsealed in the Southern District of New York charges Maduro with leading the Venezuelan narcotrafficking group Cártel de Los Soles and conspiring with the Revolutionary Armed Forces of Colombia -People's Army (FARC) guerilla group to “'flood' the United States with cocaine” and "us[e] cocaine as a weapon against America." Although the United States, consistent with international law, normally treats sitting heads of state as immune from prosecution, U.S. Attorney General Barr indicated that Maduro did not qualify for head-of-state immunity because the United States does not recognize him as the president of Venezuela. Instead, the United States and fifty-seven other countries recognize Interim President Juan Guaidó. The indictment may mark a shift in the broader U.S. policy toward Venezuela, which had largely relied on targeted sanctions against key Maduro allies to encourage defection.

After the contested 2018 Venezuelan elections, the United States became the first country to recognize Guaidó as the interim president of Venezuela, causing the incumbent Maduro and the United States to break diplomatic relations in $2019 .^{2}$ Fifty-seven other countries recognize Guaidó, but Maduro is still recognized as president of Venezuela within the United Nations, where his delegation won a seat on the Human Rights Council in October 2019. ${ }^{3}$ Guaidó

37 Id. at 23,441 .

38 Donald J. Trump, Proclamation on Suspension of Entry as Immigrants and Nonimmigrants of Certain Additional Persons Who Pose a Risk of Transmitting Novel Coronavirus (May 24, 2020), at https://www.white house.gov/presidential-actions/proclamation-suspension-entry-immigrants-nonimmigrants-certain-additionalpersons-pose-risk-transmitting-novel-coronavirus [https://perma.cc/MPC3-E3XB] (further providing that this restriction is "in effect until terminated by the President").

${ }^{1}$ Superseding Indictment, para. 4, United States v. Maduro, No. 11-0205 (S.D.N.Y. unsealed Mar. 26, 2020), available at https:/www.justice.gov/opa/page/file/1261806/download [https://perma.cc/9LKP-MA2Z] [hereinafter Maduro Indictment].

${ }^{2}$ Jean Galbraith, Contemporary Practice of the United States, 113 AJIL 601, 601, 602 \& n. 11 (2019).

${ }^{3}$ Clare Ribando Seelke, Rebecca M. Nelson, Phillip Brown \& Rhoda Margesson, Cong. Research Serv., R44841, Venezuela: Background and U.S. Relations 19 (2020), available at https://fas.org/sgp/crs/row/ R44841.pdf [https://perma.cc/99N7-HP5R]; Michelle Nichols \& Lesley Wroughton, Who Represents Venezuela? U.N., International Lenders Stuck in Limbo, ReUTERS (Jan. 30, 2019), at https://www.reuters.com/article/us-venezuela-politics-un/who-represents-venezuela-un-international-lenders-stuck-in-limbo-idUSKCN1PP00B; Alexandria 